\title{
UrbanTransport Solution An Experience From Prague
}

\author{
O. O. Jeremiah (PhD)
}

\section{Abstract}

This paper examines the urban transport problems in Prague in Czech Republic. Based on the result of the research conducted, it was found that with the collapsed of Communism in Czech Republic, there was an upsurge in the use of private cars which was not possible during communism because the law does not encourage that. This brought about much pressure on the road, thereby causing congestion on the road, increase in accidents and traffic jams. The paper also examined how the laws can be changed so that certain restrictive measures could not impede expansion of roads for improved transportation. The paper also examined how public transport could be encouraged to ease congestion and pressure on the road.

\section{Introduction:}

An efficient transport plays a crucial role in the mobility of people, goods and services from place to place or from one destination to another. The ease with which people and goods move can be said to be the barometer of progress within an economy. The transport services are expected to be available across the country for quick development. Road transport has conferred a variety of economic and social benefits in facilitating the movement of persons and goods. Flexibility as to routes, destinations, convenience as to timings, comfort in travel relatively greater safety and 
security of goods in transit, decentralised and personalised ownership of vehicles are the main direct advantages of this mode of transport. Besides, it is useful in enlarging employment opportunities, in impacting remunerative technical and managerial skills to a large number of persons engaged in road transport operations and in supporting services such as repairs/servicing units, vehicle sales and purchase agencies. However, there are some negative effects associated with road transport like its impact on environment, accidents, congestion, but these are controllable through proper management and control. In final analysis, the state and quality of transportation reflects the economic and social status of a country. As the world becomes smaller and competitive, the role of an efficient and effective road transport sector becomes more pronounced and inevitable, in the present day of globalisation of trade and industry.

Like other cities in the formerly Socialist Countries of Central and Eastern Europe, Prague has been struggling with huge increase in car ownership and use. Roadway congestion, noise, air pollution traffic jams and accidents are the other of the day. There are quite number of packed cars and scraps here and there. The scenario is disgusting and ugly. It has become a threatening menace since 1990. Through car-restrictive measures and significant improvements in public transport. However, Prague is instituted some measures to save the city' $s$ unique historic charm and to improve the quality of life for it's teeming citizens.

For a while, it seems that the Czech Republic might not escape the ravages of the transport revolution brought about by the collapse of communism and the embrace 
of Capitalism. As such, since 1988 to 1992, car ownership per 1000 population has risen from 196 to 250 , an increase of $28 \%$ (compared to $84 \%$ in Eastern Germany, $64 \%$ in Poland, and $53 \%$ in Hungary) However, in sharp contrast to the other countries. public transport use actually increased in Czech Republic. From 1989 to 1991, total urban transport trips grew by $8 \%$ over all, and in Prague alone. Automobile use more rapidly than public transport use, but the resultant decline in public transport's share of total travel was quite small, especially compared to the huge shifts in modal split in Eastern, Poland and Hungary. For an example, public transport' $s$ share of travel in Prague fell from $78 \%$ in 1988 to $75 \%$ in 1992. Unfortunately the situation in the Czech Republic has changed rather suddenly for the worse. The growing Czech Republic economy and increase in real per capital income have stimulated sharp sizes in car ownership and use. From 1992 to 1996, the rate of car ownership increased each year by about 20 cars per 1000 population, with the latest rate at 325 cars per 1000 (30\% more than in 1992) The situation has been much dramatic in Prague the largest and most important city in the Czech Republic. Prague 's car ownership rate rose from $292 \%$ per 1000 population in 1992 to 489 in 1996, an increase of $67 \%$ more than double the rate of increase for the Czech Republic as a whole.

Vehicle kilometer of car use in Prague increased even faster than car ownership, almost doubling from 1990 to 1996 (+91\% growth) motor vehicle traffic continues to grow at the rate of about $12 \%$ every year. Although there have been few expansions or 
improvement in the roadway network, the huge increase in car ownership has greatly added to the congestion on Prague 's streets, slowing down travel, both for cars and buses and trams that ply on the streets. On morning and afternoon rush hours, or peak hours, traffic on important arteries often comes to a standstill. When moving, however, Prague's cars have become dangerous indeed, maiming and killing many people. In 1995, about 123 , ie $31 \%$ more than in 1990.

As car ownership and use increases, almost every kind of public transport has been losing riders since 1992 throughout the Czech Republic. Long distance rail road travel, for instance, declined by $24 \%$ from 290 million passengers to 219 million passengers from 1992 to 1996. Rural and intercity bus travel decline even more drastically, from 1422 million passengers in 1996, a $37 \%$ decline. Hence, urban public transport cost $28 \%$ of its passengers in Czech cities over all and $29 \%$ in the capital city of Prague between 1992 and 1996. These declines are as of fact more noticed because (in contrast to Eastern Germany Poland and Hungary) Public transport use had really increased from 1988 to 1992. Whereas public transport' $s$ share of travel in Prague decline slightly in the sample time period, it 's modal split doubled between 1992 to 1996. As at today, the share of public transport is only $60 \%$ of trips in Prague slightly higher than Budapest and Warsaw. There might be the argument that the shift from pubic transport to the private car usage in the Czech Republic, as in the rest of Central and Eastern Europe is natural outcome of market choices reflecting enormous popularity of the car. Naturally, supporters of this view would probably not see the enormous 
increase in car ownership and use as problematic at all in terms of traffic hold ups, congestion on the road, except when they are stuck in traffic jams themselves. The true fact is that, Czech cities are not built to handle such high volume of cars traffic. The capacity of their roadway networks is quite limited, and the high density of urban development makes roadway expansion both difficult and undesirable in most situations. Further, the old towns of many Czech cities are protected by historic preservation laws, which would prevent any significant modernization of the central road network. In Prague for instance, $8.6 \mathrm{sq}$. kilometer of the city centre has been legally protected historic district since 1971 .

Moreover, there is not nearly enough space to park so many cars. Eventually it might be possible to construct high capacity, parking garages, but such facilities are currently almost totally lacking in Prague and every other Czech city.Most cars are usually parked in any way that has got space, legal or illegal on side works street, in vacant lots, and even on tram tracks. Even Prague' $s$ most beautiful square (Malost ranske Namesti) has a large parking lot for members of the National Parliament. One can hardly image a less appropriate use of this precious space. It seems the powerful Parliamentarians prefer their own convenience to the preservation at this unique district, just, as auto drivers in general ignore the social, environmental and aesthetic impacts of car use. The chronic traffic congestion, air, noise pollutions and litter of packed cars all over the city diminish the unique charm of Prague, surely one of the most beautiful and historic cities in the world. Transport and land use policies in Communist Czechslovakia, were very different from 129 
current policies. Under socialism car ownership and use were drastically restricted. The government directly set the prices of both cars and (gasoline) petrol. Compared to all other socialist countries, most Czechs simply could not afford to purchase or own cars, talk less use them for daily travel. Even as car ownership increased during the 1970s and 1980s, most cars were used for trips to the countryside on weekends and holidays. As at 1988 only $10 \%$ Czech used a car for the journey to work. Thanks to the large subsidies from the Central Government, public transport services were ubiquitous and very expensive, thus , further discouraging car use.

Both the Socialist Central Government and the Prague municipal government undertook a range of measures to reduce car use in central Prague in particular. Between 1971 to 1985 ,Prague become the first European city to establish traffic in its entire centre. This include extensive pedestrian zones, 24 streets closed to private cars and most other streets restricted to local traffic only. Through traffic routed around the city centre, the volume of car traffic fell by $59 \%$ in spite the increased car ownership. At the same time the city of Prague sharply restricted parking in the centre, giving priority to local residents and businesses, but still requiring them to pay fees for the necessary annual permits.

With the "Velvet Revolution " of 1989 many of these policies changed. The first change was a sharp reduction in central government-subsidy to public transport whereas the central government had financed all the capital investment and operating subsidy prior to the revolution. Most of the burden has shifted to the 
city of Prague itself. Further, the city government bears $100 \%$ of metro capital cost .(reconstruction, vehicle replacement, modernization, and line extensions) and all infrastructure costs for all other modes of public transport. The only remaining contribution from the central government is a $10 \%$ matching subsidy for a new buses and a 30\% matching subsidy for new vehicles. Currently the central government pays only about five percent of the total subsidy in public transport in Prague .The remaining $95 \%$ must be financed by the city of Prague and that has consumed about $33 \%$ to $40 \%$ of the budget of the city for the years 1992 and 1995. Clearly it has become more difficult than ever for public transport to compete with the private automobile. With the levels of car ownership roughly twice as high now as during the 1880s, public transport must offer high quality services and attractive fares . Unfortunately, Dopraveni Podnic has been forced to raise fares several times, and that has, probably caused some loss of passengers, as described later. The main focus has been on improving overall service quality by expanding , modernizing, and integrating services. The backbone of the public transport system in Prague has been its superb metro system overall. Hence the metro system was extended by another six kilometer, in 1980, bringing the total length of the three metro lines to $50 \mathrm{~km}$. There are plans for a subsequent four $\mathrm{km}$ extension. Further, another planned seven $\mathrm{km}$ extension are in the pipe line. In addition to expanding the metro system, Dopraveni Podnike is modernizing its stations, replacing escalators and building additional exits for greater rider convenience comfort. The oldest metros are 
being taken out of the service and replaced with new ones. The remaining cars are being reconstructed and modernized to improve energy efficiency, dependability and passenger comfort.

The tramway network in Prague, one of the largest in Europe, covers $136 \mathrm{~km}$. A new six km. light rail line was opened in Southern Prague in 1995. Three more extensions have been approved and are either under construction or planned, adding another $13 \mathrm{~km}$ of light rail by the year 2002. Almost $28 \mathrm{~km}$ of further extensions has been mapped out, but that has not been approved for financing. Exit lines has been approved through extensive modernizing of tracks, including complete reconstruction of tracks and track beds over key routes. Moreover, trains are being given traffic signals priority of more and more intersection (currently 31) with signals turning green for in coming trains and red for cars.

That obviously helps speed up train travel, Depraveni Podnike is gradually replacing its old fleet of tram vehicles (with an average age of 17 years) .Between 1996 and 1998, for instance, 150 brand new tram cars not retired from service are being modernized to improve their performance.

As in all cities, buses provide important feeder and distribution services to get passengers to and from the rail lines in Prague. Thus, most of the 2105 $\mathrm{km}$ of bus routes are in lower density area of the city which are not yet served by metro or light rail. Probably the most important improvement in bus service has been the replacement of buses since 1990. Then, the average age is less than 5 years. 
A particularly important development in Prague has been the improved integration of public transportation service throughout the Prague metropolitan region. In 1993, the city of Prague created a new transport agency called ROPID. Its most important function is to provide better public transport services to the growing suburban population in outlying towns and villages. For the first time, ROPID fully integrated suburban rail and bus services into the overall public transport system of Prague, coordinating its service and fare with Dopraveni Podnike. Since its inception in 1993, ROPID has established 38 new suburban bus $r$ routes. It has enhanced the suburban rail services by introducing a more regular service (of course every hour or half hour), enabling travelers to use certain long distance trains, and allowing the same ticket to be used for both suburban rail and the metro, trains and bus services in the central city services and fare integration are perhaps not as complete as in the Verkeherbund found in Germany, Swiss and Australian cities, but ROPID is considerably ahead over the previous fragmentation. Expanding and improving services in the rapidly growing suburban of Prague will be essential to capturing future market.Dopraveni Podnike is fully aware of the need to hold onto current riders, and to attract new riders in the years ahead. In addition to expanding and improving, its entire range of public transport services, Dopaveni Podnike has entered to aggressive marketing its services to the public to encourage more riders. Instead of taking customers for granted, as witnessed the past 40 years of socialism , the public transport system in Prague is utilizing a variety of marketing strategies used for many years in 
Western Europe. For instance, it has worked closely with all the Prague radio and television stations to advertise service improvements and changes in fare policy.

The mass media have been crucial in the campaign to educate the public the many social and environmental benefits of public transport, and its key role in improving the quality and standard of life in Prague. More and more transport information centers at strategic metro stations providing customers with maps, time tables, informational brochures, and answers to specific questions as well as the entire range of tickets for sale. Periodic mass mailing and newspaper inserts ensure that virtually all Prague have the information they need. Dopraveni Podnike has tried to keep fare as low as possible, but limited by the subsidies received from the city of Prague. Since 1991, Passenger fare revenues have covered about one-fourth of operating expenses with little variation from year to year . (23\% to $25 \%)$, Hence the extent of operating subsidy in Prague remains very high indeed, and capital subsidies cover all the cost operating investments in new rail lines and vehicles, nevertheless, the price of a regular one way ticket increased 10 -fold between 1990 and $1996(+900 \%)$ while petrol prices rose only $152 \%$, which is less than the overall $175 \%$ rate of inflation. The purchase price of a new standard car rose by $210 \%$ exceeding the $b$ rate of inflation but still only a fraction of the increase in public transport fares. Fortunately, the prices of monthly, quarterly . semi-annual and annual tickets have not increased as fast as single-trip ticket price. Consequently, most public transport passengers in Prague use seasonal passes, 
with only $11 \%$ buying single-trip tickets. In spite of the improvements, the net result is that public transport has become very expensive relative to car ownership and use. Certainly that is one reason for declining public transport use since 1990.

Public transport system in Prague and throughout Eastern Europe desperately needs dedicated source of funding. As already noted, Prague 's municipal budget strained to the limit and as such cannot afford to spend over half of its revenues on public transport. The ideal solution to public transport 's funding problems is increased taxes and charges on car ownership and use. Higher petrol taxes, sales and import taxes on new cars, parking charges, and motor vehicle registration fees would all generate a dependable stream of revenues that would increase overtime and which could be dedicated to funding improved public transport services and lower fares. This would both discourage excessive auto use and provide car drivers with a better a better public transport alternative to driving. Increased taxes on auto ownership and use can only be implemented by the central and municipal governments. However, the conservatives government of Vaclav Klavs views the increase in car ownership and use since 1990 as logical outcome of consumer preferences for the car in private market.

Indeed, it has offer $3 d$ 100\% subsidy , funding for various roadway construction $b$ projects to serve the huge increase in car use. Further, it has opposed attempts to raise taxes on cars and petrol. While accommodating growth in car ownership and use, the 
Klavs administration has sharply cut subsidies to public transport.

In contrast, the municipal government in Prague has redoubled its efforts to control automobile use. Foremost among its progressive policies is the large increase in city subsidies in public transport and its commitments to greatly improve public transport in the years ahead. Equally essential, however, is the city' s strengthened commitment to greatly restricting car use in central Prague. It has expanded the car restrictive measures introduced under socialism, at least in the historic old town. Pedestrian zones, car-free streets, traffic calming and central neighborhoods and exclusion of non-local traffic have all helped. The city has $v$ been adopting some car restrictive measures already used for many years in Western Europe : for example, at 31 metersections trams now have automated priority in traffic signals . After five years of extremely tax parking regulations (1989-1994) described by one Prague official as " parking chaos", the city of Prague has introduced a zonal parking system in the centre. Not only are most parking spaces reserved for the local residents and businesses, but they must pay substantial fees for the annual permits required. Residents pay 500 czech crowns for a second car. Business houses pay 50,000 crowns per vehicle. To help deal with the severe parking problems in Prague, a private company (Euro park) has been commissioned to administer the sales of parking permits $b$ and operate on-street parking meters. The new parking control system only came into full effects in may 1996 and it is not yet clear how 
effective it will be, but at least it is a step in the right direction

The future of Prague and other cities of central and Eastern Europe largely depends on improved public transport stricter controls on auto use, these cities will be drown in a sea of car. Roads will become even more congested, air and noise pollution will rise further, and rising accidents rate will make the cities even more dangerous. This is not a matte of saving the cities themselves. It would be a tragedy if Prague, Central Europe 's most beautiful city, is allowed to be destroyed by waves of cars. A lot of lessons have to be learnt from the experience in Prague. I am suggesting that the planners in Lagos-Nigeria and Addis Ababa, and elsewhere should take cognizance of the experience in Prague and thus redesign their transport plan that will accommodate adequate parking space for vehicles, encourage the use of public transport, to make necessary amendment that impedes the expansion of roads. Taking corrective measures now will be of most help the planners.

\section{Conclusion:}

With the exit of Communism in Czech Republic and adaptation of Capitalism and market driven economy, there has been increased use of private car ownership. This has greatly affected the transportation system in the country especially Prague. Lots of restrictive measures have to be adopted to save the city. Public transport has to encouraged to ease traffic jam and accidents on the roads. The laws has to be amended to enable the road planners to be able to 
expand the roads to accommodate both transporters and pedestrians because the city has been protected by old laws making it difficult to undertake road expansion. More parking spaces were provided to ease the road congestion.

\section{References:}

Atkinson,B.A.H and Jarvis, R.(1995): Business accounting For Hospitality and Tourism.

Brent, J.K. and Charles, G.R.(1994):Travel tourism and hospitality Research-A Handbook for managers and Researchers-second edition.

Dimilrios,B.(2003): Tourism information Technology for Strategic Tourism Management- Ft Prentice Hall.

Ediin, B.F(1996): Personnel Management Issues and Problems.

Gupta,C.B.(1993): Management theory and practice Sultan Chand and Sons New Delhi.

Micgregor,D.(1992): An uneasy look at performance Appraisal, Harvard Business Review vol.50 3-8pp.

Rao, T.V.(1985): Appraising and Developing Managerial Performance, Academy of Human Resource Development Ahmedabad India.

Rob, D.and Benlad, C.(1994,2003): Business Travel Conferences Incentives Travel. 